\title{
A Data-Driven Analysis on the Impact of High-Speed Rails on Land Prices in Taiwan
}

\author{
Joyce M.W. Low ${ }^{1}$ and Byung Kwon Lee ${ }^{2, *}$ \\ 1 Lee Kong Chian School of Business, Singapore Management University, Singapore 178899, Singapore; \\ joycelow@smu.edu.sg \\ 2 Department of Industrial Systems and Management, National University of Singapore, \\ Singapore 117576, Singapore \\ * Correspondence: leebk@nus.edu.sg; Tel.: +65-6601-7304; Fax: +65-6777-1434
}

Received: 15 April 2020; Accepted: 6 May 2020; Published: 12 May 2020

check for updates

Featured Application: This study examines the extent to which the introduction of HSR increases land prices and how the effect on land prices will vary with the stages of economic, societal, and infrastructural developments in different cities of Taiwan.

\begin{abstract}
High-speed rail (HSR) networks boost inter-city accessibility across a country and stimulate economic growth in inner cities. These economic gains, however, can often be accompanied by sharp increases in land and property prices along the lines that raise governmental concerns. This study examined the effect of the introduction of HSR on land prices in Taiwan and how the extent of such an effect varied with the stages of economic, societal, and infrastructural developments in different cities in Taiwan. Based on extensive published data, an empirical study was conducted using an integrated methodology comprising system dynamics, multivariate regression, and principal component analysis to examine the interacting relationships between the presence of HSR transportation and other important dimensions of city development in determining land prices. The study found that while land prices correlated with the greater locational accessibility brought about HSR, the extent of land price increases depended significantly on economic, societal, and infrastructural considerations such as the unemployment rate, risk-free interest rate, population density, and the existence of free trade zones, etc. This understanding of system behavior will be helpful for policy makers in devising ways to curb the escalation of property price while enjoying the benefits of HSR.
\end{abstract}

Keywords: locational accessibility; real estate prices; system dynamics; multivariate regression; principal component analysis

\section{Introduction}

Taiwan's high-speed rail (HSR) network, which opened in January 2007, spans some $345 \mathrm{~km}$ from Northern to Southern Taiwan along the Western Corridor where the majority of the country's population are centered. The HSR line consists of twelve stations, with the initial eight stations opening in 2007, followed by the other four in 2010 (Figure 1). Before the introduction of the HSR, commuters needed five hours to travel from Taipei to Kaohsiung by bus or conventional rail, and this inaccessibility restricted population and commercial growth outside Taipei and widened the economic gap among regions. With the HSR, the total travel time has drastically reduced to ninety minutes from Taipei to Kaohsiung and no more than $2 \mathrm{~h}$ from Taipei to Tainan. According to a survey on the long-term usage patterns of HSR in Taiwan and Shanghai, the improvement in accessibility is the prime reason accounting for the significant increase in HSR usage, with the speed advantage and travel time savings being the main motivation for commuters to choose to travel on the HSR [1]. 


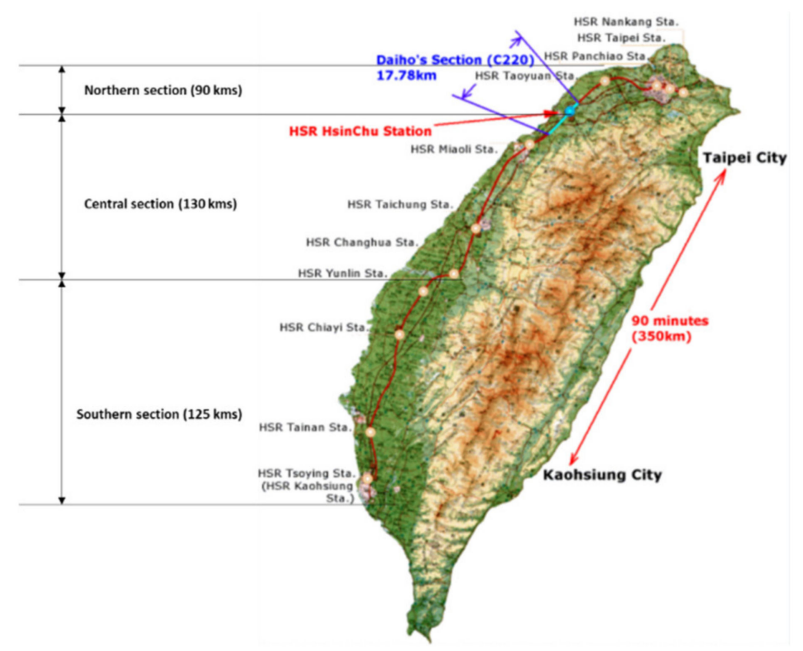

Figure 1. Stations of Taiwan's high-speed rail (HSR) line [2].

While HSR brings about benefits, such as increased accessibility, time savings, and higher productivity, the resulting economic gains are also accompanied by a significant increase in land value and property prices along the HSR lines. According to Kanasugi and Ushijima [3], house prices have jumped by $14.67 \%$ following the introduction of the HSR. On the contrary, it is also noted that house prices showed an increasing trend even prior to the introduction of the HSR lines in 2007 (Figure 2). Instead, the monocentric layout of many Taiwanese metropolitan areas was previously found to give rise to the relationship between residential property prices and the distance to the central business district (CBD), and to a lesser extent, the distance to the nearest HSR station $[4,5]$.

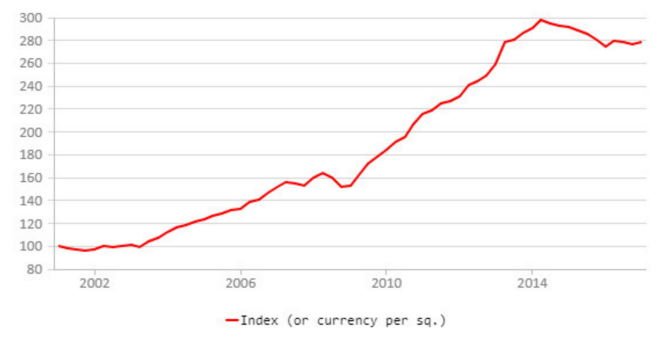

(a)

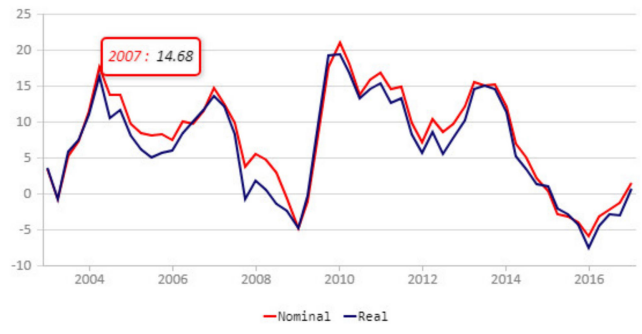

(b)

Figure 2. Lutheran home price index $(\mathrm{Q} 12001=100)(\mathbf{a})$ and the change in house price $(\%$ change over a year earlier) (b) in Taipei, Taiwan [6].

Since 2013, Taiwan has ranked fourth as the hottest property market in the world with the house-price-to-income ratio of Taipei City being the highest globally $[7,8]$. According to the Ministry of the Interior of Taiwan, the house-price-to-income ratio rose to 9.2 in 2013. This ratio indicates that it will take more than nine years for a person to own a property if they put their entire salary towards mortgage payment. While modest rises in house prices will give a boost to economic recovery, a continued rise in house-price-to-earnings ratios leaves great cause for concern from a longer-term perspective. Many house buyers will need to take out larger mortgages in order to get on the property ladder, making the economy more vulnerable and sensitive to future interest rate movements. It also leaves the possibility that in the event of a future house price falls, living standards will be negatively affected, as many younger people will struggle to pay their housing costs. From a societal point of view, the large disparities among house prices in different locations impede geographical mobility, as expensive house prices make it more difficult for people to move around the country. Equally undesirable is the widening of inter-generational wealth inequality brought about by rising house prices which divides the country into those who inherit a house from their previous generations and those who do not. 
Indeed, increasing the housing-prices-to-income ratio is a concern in many cities around the world, as the affordability of housing affects the social security of the people in a country.

The factors influencing house prices are diversified and complex. Generally, the housing market is influenced by the state of the economy, interest rates, and real income which determine the affordability of housing with speculative demand putting pressure on house prices on top of changes in the size of the population. In addition to these demand-side factors, house prices will be determined by the available supply, which is an aggregation of the number of sellers and the volume of new builds. Within a country or even within a city, property prices can vary significantly across specific locations depending on factors such as access to urban areas and proximity to amenities. Since HSR significantly enhances the locational accessibility, it can potentially increase the property prices in neighboring areas surrounding the HSR stations.

This study seeks to contribute to the understanding of the associations between the introduction of HSR and land prices in Taiwan under the considerations of a spectrum of societal, economical, and infrastructural representative elements including population sizes, economic growth, lending rates, road densities, presence of an airport, provision of public goods such as education, etc. Specifically, the study quantified the impact of the introduction of HSR on land prices in the cities along HSR lines in the period 2005-2016 inclusive. A single-line network with only two primary stages of development provided the boundaries for the scope of the analysis. Based on extensive published data, the directional flows of the representing elements into the societal, economical, and infrastructural stocks were investigated by means of system dynamics (SD). A series of hypotheses on the interactions among these elements was represented in a stock and flow diagram. While SD is an approach to depicting the behavior of complex systems over time, the analysis was supplemented with multivariate regression that determined the relative impact of the elements categorized broadly into the HSR's accessibility, social relevance, economic growth, and residential infrastructure on land prices. Subsequently, recognizing the impact of HSR on property prices is also dependent upon the stage of economic, social, and infrastructure development, and principal component analysis (PCA) was used to extract the underlying structure of the system. In view of the large datasets from the large number of elements considered, PCA was the preferred adaptive technique for reducing the dimensionality of the datasets and increasing interpretability while minimizing information loss by creating new uncorrelated dimensions (i.e., the principal components) that successively maximized variance. The principal components were reduced to solving an eigenvalue/eigenvector problem, and the new dimensions were defined by the dataset at hand. The statistical significances and association levels of the elements that were obtained indicated the tradeoff between each element and its association with land prices. The interactive relationships among ttthe presence of HSR and other dimensions are helpful to the authorities iin devising ways to curb spikes in property prices while benefiting from the improved accessibilities brought about by HSR. By having a clearer understanding of the structure of the system over the 12 year period from 2005-2016, it will also improve the prediction of how land prices will change in response to the economic, societal, and infrastructural developments of the cities in Taiwan.

\section{Related Literature}

The key benefit of having a HSR system is the enhanced accessibility that the HSR network will bring to an economy. Since locational accessibility is a major determinant of property and rent prices, many researchers have investigated the impact of accessibility on the property (housing) price. Much of these studies are built upon the hedonic price model [8]. Andersson et al. [4,5] examined the effect of the accessibility of HSR stations on housing prices in seven individual cities in Taiwan where the stations are located, via various non-linear regression models such as log-linear, semi-logarithmic, and the Box-Cox-transformed functions. The variables examined were categorized into structural attributes (floor area, lot size, age, etc.), neighborhood attributes (road width, commercial zone, residential zone, etc.), and accessibility attributes (distance to the CBD, distance to the HSR station, distance to science/industry park, etc.). The authors found the HSR's accessibility effects were significant but 
minor; other factors, such as commercial activities, the opportunity cost of not living in the destination community, etc., had a greater effect than the proximity of the HSR station. Chen and Haynes [9-11] studied the effect of HSR station accessibility on housing values by applying a robust ordinary least squares method, Box-Cox transformation, and a spatial econometric model to 22 capital and non-capital cities along the Beijing-Shanghai line. The accessibility measures were modeled as either distance or time in the models. The experiment's outcomes showed that the distance impact of HSR stations was insignificant in the capital cities, but both local and spillover effects were found in the non-capital cities.

Geng et al. [12] demonstrated the effects of HSR stations (Beijing South Railway Station) on housing prices for positive (accessibility to the station, investment attractiveness, and public service infrastructures) and negative factors (noise, pollution, and congestion). From the proposed multiple regression model, the authors found the geographical spatial ranges addressing the positive or negative correlation between the HSR station and the house prices. Brandt and Maennig [11] also found the different effects on condominium prices according to the accessibility ranges of the rail station in Hamburg, estimated by a basic hedonic pricing model as well as a model with interactives. Both Geng et al. [10] and Brandt and Maennig [11] showed that distance accessibility has a significantly positive association with housing price when the distance is neither too close nor too far. More recently, Kanasugi and Ushijima [3] analyzed the land price benefit of HSR across six cities (i.e., Tokyo, Kanagawa, Yamanashi, Nagano, Gifu, and Nagoya) along the Linear Chuo Shinkansen line in Japan, the construction of which was announced in 2011 and is scheduled to open in 2027. The empirical analysis showed that the construction information disclosure takes an immediate effect on the increase in residential land prices when there is demand for time-distance shortening.

Along with transportation-enhanced accessibility brought about by a comprehensive transportation system, the noise nuisances from vehicle traffic and their impact on property prices cannot be ignored. Based on an acoustic map for the city of Olsztyn, Szczepańska et al. [12,13] first determined the traffic noise intensity for apartments. Next, the values of the noise depreciation sensitivity index (as defined by the percentage change in property prices per $\mathrm{dB}$ increase in noise levels) were calculated, and the distribution of the unit prices of apartments was mapped relative to noise levels. Subsequently, linear correlations between the unit prices of apartments and noise levels were analyzed. The strength and direction of the relationships among the analyzed parameters were determined based on Pearson's correlation coefficient. In the last stage, the distribution of the unit prices of apartments was mapped by ordinary kriging, a geostatistical estimation method. The study concluded that a significant negative correlation of noise elements on property prices existed by comparing the spatial distribution of traffic noise levels measured during the first stage with the spatial distribution of apartment prices. In Shelby County, Tennessee, Ozdenerol et al. [14] studied the effect of traffic noise and how it is systematically capitalized into the house value discount. The authors used the speed and volume values of traffic flows on the road and railroad transportation systems as inputs into a noise prediction model. It was found that traffic nuisance, in general, has a significantly negative impact on housing values, and the discount on housing values increases with the noise nuisance levels. Furthermore, the increased intensity of traffic volume within the Memphis Aerotropolis boundary leads to a further decrease in housing values. In a very recent study, Kuehnel and Moeckel [15] investigated the influence of simulated car traffic noise on real rent prices. The study showed that modeled noise values from the transportation model were able to explain significant impacts on rent prices when using a hedonic pricing regression. Other classical research on the impact of highway noise on property prices include Hall et al. [16] and Taylor et al. [17].

Apart from accessibility and transportation-induced noise pollution, other elements are also known to affect property prices in the real estate market. For example, Karanikolas et al. [18] saw that the qualitative characteristics of the natural and human environment, such as proximity to urban green spaces, water resources, unusual topography, and possible future or past manifestation of natural disasters plays a role in determining property prices. Getzner et al. [19] highlighted the importance of landscaping. Ersoz et al. [20] singled out the size of the property, the distance to the city center, 
the popularity, and the age of the building as variables that have the most impact on the unit price in Turkey. In addition, other studies have been debating the positive and/or negative effect of HSR on the labor market (employment), regional economic growth, and the regional population, etc. [20-26]. These studies show that there are not always positive effects found in the relationships among regions, but the location and other economic conditions of the region can also become significant determinants.

\section{Application of System Dynamics}

This section provides an overview on how various elements of stocks, such as "accessibility", "economy", and "infrastructure" developments and "social" settings, affect land prices and proposes flows of the constituents to and out from these stocks. By capturing interactions and, consequently, the feedback loops, a causal loop diagram reveals the dynamic structure of a system, where each of these components exert a positive or negative effect on the land prices directly or indirectly.

Morris et al. [27] defined accessibility as the ease at which transport systems allow activities or destinations to be reached by individuals. According to land theory, land values reflect higher accessibility gradients. Locations with better "accessibility" tend to have higher land values $[28,29]$. It is postulated that improved accessibility arising from HSR, supported by high "road density", can increase land values through a reduction in traveling time and cost. Property prices increase with higher demand for accessible housing locations, as more people are willing to pay for the benefits of convenience $[10,11]$. Meanwhile, it can be counterargued that the noise pollution brought along by the road traffic adversely affect property prices $[12,13,15]$. Improving accessibility also effectively reduces transportation costs and brings manufacturing activities closer together, leading to concentrated locations of production that promote the exploitation of economies of scale. Consequently, such industrial development increases employment in the area and the attractiveness of the neighborhood. The contribution of a new HSR station is felt even stronger in the absence of an airport in proximity, not forgetting the noise from an airport erodes property prices [14]. The "unemployment rate" is likely to move in the opposite direction to property prices [30]. A rise in unemployment reduces "consumer prices" and property prices as consumption and demand for housing fall [31]. The consumer price index (CPI), which is a weighted average of prices of a basket of consumer goods and services, such as transportation, food, and medical care, is a generally accepted proxy to inflation. Housing becomes less affordable for the general populace when the CPI increases and the real-estate-price-to-income ratio increases. The relationship between income and land prices becomes even more significant in regions with higher rates of unemployment, because demand for housing becomes more price elastic [32]. On the other hand, Branch et al. [33] suggested that if homeowners are to use home equity as collateral to finance idiosyncratic consumption opportunities, such financial innovation that raises the acceptability of homes as collateral raises house prices and reduces unemployment.

Economic growth forms the foundation for robust property prices and accounts for appreciation in prices, suggesting a close link between the property market and the economy [34]. Economic development leads to higher land prices with the increase demand for land used in "commercial activities" such as retailing, accommodation, and other exhibition or conference facilities. While the "number of companies" in an area influences the amount of "commercial activities", "locational accessibility", the presence of a "free trade zone", "exchange rates", and the degree of "internet penetration" are some elements that attract the establishments of companies. Florida [35] asserted that the most connected countries tend to be highly urbanized. The opening of HSR stations increases the physical connectivity of previously remote cities. Favorable exchange rates reduce the cost of imports. With investors being drawn to invest in these smaller cities, the number of businesses consequently increases [36]. "Internet penetration" increases communication connectivity and facilitates commercial activities in an area [37]. In addition, many stations on the Taiwan HSR line serve as gateways to tourist attractions in Taiwan. High-speed rail is is an attractive travel option for tourists who are limited by the length of the trip, as it allows for one-day trips and faster travel times between destinations. As the "tourism" industry grows, economic flows shift to accommodate 
the rising demand for related goods and services, such as hotels, restaurants, and other attractions, and trigger a dramatic increase in "building costs" and land values [38,39].

Interest rates, being reflected in the borrowing rate for depository institutions, is a key factor in determining the cost of establishing a business and property price. The strong linkage between property and interest rate is not surprising given the heavy reliance on mortgage financing in the housing market $[40,41]$. Apart from reducing mortgage rates that drive up property prices, lower interest rates induce consumption which raises the consumption rate and profitability of companies while injecting inflation into the economy. Indeed, Tsatsaronis and Zhu [42] found that inflation is among the key determinants of housing prices in a number of industrialized economies. Related to the cost of housing is the construction cost making up of fuel prices (as reflected by the energy price), building costs, and import material costs. According to Somerville [43], increases in the cost of construction should reduce the supply of new housing, but empirical research has failed to find a consistent relationship between these costs and housing.

Other infrastructures, such as local public goods and education institutes, also play a significant part in driving property prices. The availability of various types of facilities and amenities affects the valuation of property prices, as it draws individuals and businesses to relocate nearby, especially for those that improve standards of living and the quality of life [4,5]. At the same time, new transportation systems, such as an HSR, can affect the "population density" in the location served by the rail system thus influencing the government decisions on infrastructure development. The population distribution reflects the "social" setting of a country, with higher population growth and population density driving the demand for residential properties [44]. According to Feng [45], the Western Corridor of Taiwan holds $94 \%$ of the country's population and densities average around 750 persons $/ \mathrm{km}^{2}$. Property developers will be attracted to develop pieces land into housing and residential communities, thereby increasing competition for the land which could be developed for other uses such as shopping malls or office buildings. When the rate of increase in demand for houses is faster than that of supply, residential property prices will rise. Furthermore, the closer the land is to the population center, the greater the value of the land. In contrast, land prices decrease with increasing distance from the city center [46]. Taiwan has urban projects that aim to develop lands surrounding HSR stations, according to the Bureau of High Speed Rail [47]. Some examples are airport-related industries, and urban logistics support have sprung out in the vicinity of Taoyuan Station. Further postulated relationships among the components and stocks are summarized in Table 1.

Table 1. Linking up the relationships of the causal loop diagram.

\begin{tabular}{|c|c|}
\hline Relationship & Explanation \\
\hline $\begin{array}{l}\text { HSR } \rightarrow \text { Accessibility } \rightarrow \text { Tourism } \rightarrow \\
\text { Commercial Activity } \rightarrow \text { Economic growth }\end{array}$ & $\begin{array}{l}\text { Greater accessibility attracts a larger influx of tourists which, in turn, stimulates a greater demand } \\
\text { for goods and services (commercial activities generated) and stronger economic growth. }\end{array}$ \\
\hline $\begin{array}{l}\text { Accessibility } \rightarrow \text { Population } \rightarrow \text { Population } \\
\text { Density } \rightarrow \text { Infrastructure } \rightarrow \text { Land Price }\end{array}$ & $\begin{array}{l}\text { The more accessible a location is, the greater the ease of commuting thus attracting people to live } \\
\text { there. More land is required for infrastructure to support the growing population, contributing to } \\
\text { higher land prices. }\end{array}$ \\
\hline Distance to airport $\rightarrow$ Population & $\begin{array}{l}\text { Although proximity to the airport represents greater accessibility, negative externalities resulting } \\
\text { from low-flying aircraft may discourage residents from living in nearby areas. }\end{array}$ \\
\hline $\begin{array}{l}\text { Free trade zone }(\mathrm{FTZ}) \rightarrow \text { Number of } \\
\text { Companies } \rightarrow \text { Commercial Activity }\end{array}$ & $\begin{array}{l}\text { The ease of doing business in an area serves as a pull factor for businesses, therefore increasing } \\
\text { commercial activities and demand for land. }\end{array}$ \\
\hline $\begin{array}{l}\text { Internet Penetration/Tourism } \rightarrow \\
\text { Commercial Activity } \rightarrow \text { Economic growth }\end{array}$ & $\begin{array}{l}\text { The greater the rate of internet penetration and the size of the tourism industry, the more attractive a } \\
\text { location for commercial activities. }\end{array}$ \\
\hline $\begin{array}{l}\text { Unemployment Rate/Energy Price Index } \\
\quad \rightarrow \text { Affordability } \rightarrow \text { Land Price }\end{array}$ & $\begin{array}{l}\text { The lower the unemployment rate and the costs of utilities, the higher the affordability of a location } \\
\text { and the higher the land prices. }\end{array}$ \\
\hline $\begin{array}{l}\text { Construction Cost } \rightarrow \text { Amenities } \rightarrow \\
\quad \text { Infrastructure } \rightarrow \text { Land Price }\end{array}$ & $\begin{array}{l}\text { Lower construction costs increase the economic feasibility of construction projects. The resulting } \\
\text { higher level of amenities (and overall infrastructure) available increases land prices. }\end{array}$ \\
\hline
\end{tabular}


Figure 3 below shows a causal loop diagram with all its stocks and constituent components described earlier and their combined effect on land prices. The stocks are accessibility, economy, social, and infrastructure. There are two types of feedback loops in this diagram. For example, positive reinforcement indicates that the presence of an HSR station, a long distance to the airport, and a high road density would increase the amount of accessibility that an HSR brings to the area. A negative reinforcement of a long distance to the airport or the size of the population suggests that the increased accessibility brought about by the HSR would positively contribute to the size of the population and population density that eventually leads to higher land prices.

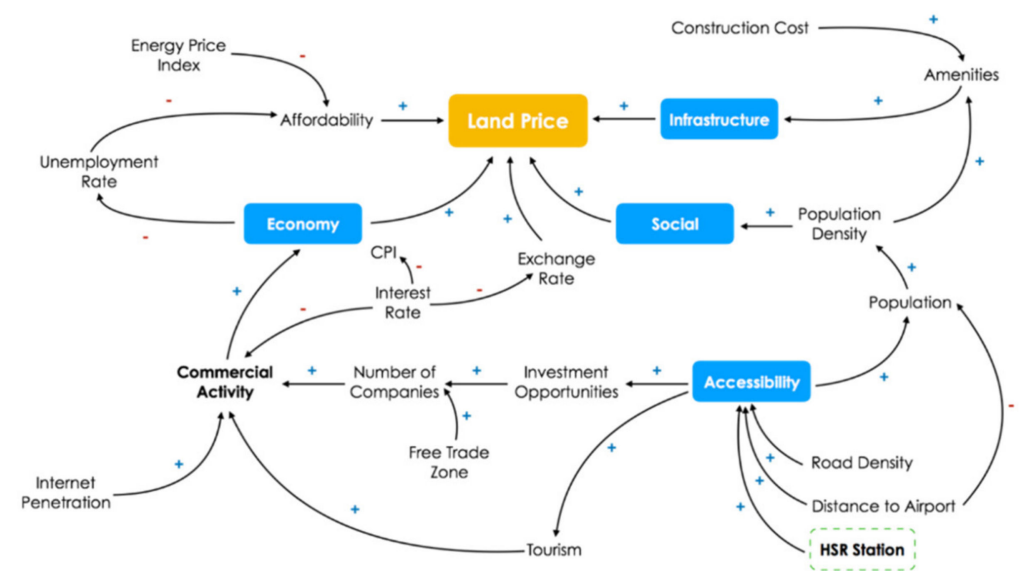

Figure 3. Causal loop diagram for land prices.

While positive and negative feedback loops may act simultaneously, at different times they may have different strengths. The proposed directions of relationships were identified and verified by observing the degree of positive and negative associations based on a collected dataset of each pair of components or component and stocks in the next section.

\section{Data-Driven Analysis}

This study used the Urban Land Price Index (ULPI) as the measure of property prices in 11 cities in Taiwan. These cities were Taipei, Kaohsiung, Taichung, Tainan, Hsinchu, Taoyuan, Keelung, Hualien, Yilan, Taitung, and Nantou.

The ULPI is derived from the market value of ten survey sites within each city which were analyzed as if they were vacant plots of land, regardless of their current use as commercial or residential developments. An examination of commercial rentals, the Residential Property Price Index (RPPI), and the Urban Land Price Index (ULPI) found that the correlations between RPPI and ULPI as well as between commercial rentals and RPPI were above $90 \%$ (Figure 4). This provides strong evidence that ULPI is a well-representative proxy for both commercial and residential property prices. Since property and land prices exhibit a strong positive correlation with each other, property and land prices were used interchangeably in this analysis. For simplicity, it was assumed that the prices of land and properties within each city is uniformly distributed. 


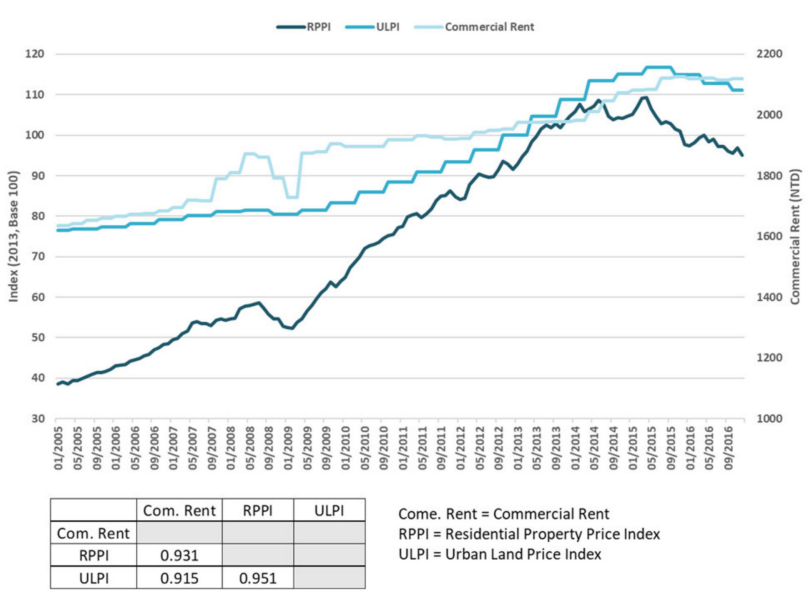

Figure 4. Correlations between land prices and property prices.

From the components discussed in Section 3, sixteen explanatory variables were identified to have an impact on the stocks (i.e., locational accessibility, economic development, supporting infrastructure development, and social setting). Table 2 summarizes these variables and their expected relationship with land prices-either positive (+) or negative (-).

Table 2. Possible factors affecting land prices.

\begin{tabular}{|c|c|c|c|}
\hline Notations & Variables & Expected & Rationales \\
\hline HSR & $\begin{array}{l}\text { Existence of High-Speed } \\
\text { Rail Station }\end{array}$ & + & $\begin{array}{l}\text { Higher connectivity should attract more demand for residences/business, } \\
\text { thus driving land prices up }\end{array}$ \\
\hline$H \$ I$ & $\begin{array}{l}\text { Housing Price to Income } \\
\text { Ratio }\end{array}$ & - & $\begin{array}{l}\text { When the H\$I ratio increases, people are less able to afford houses, thus } \\
\text { demand falls, causing the land prices to fall }\end{array}$ \\
\hline UnEmp & Unemployment Rate & - & $\begin{aligned} \text { Higher Unemployment } \rightarrow & \text { Fewer people can afford housing } \rightarrow \text { Land } \\
& \text { prices decrease }\end{aligned}$ \\
\hline CPI & Consumer Price Index & + & Inflation leads to land prices increase \\
\hline Forex & Exchange Rate & + & $\begin{array}{l}\text { Higher exchange rate/US\$ } \rightarrow \text { Weaker TWD } \rightarrow \text { More foreign investment } \\
\text { in property/land entering Taiwan } \rightarrow \text { More demand } \rightarrow \text { Higher land prices }\end{array}$ \\
\hline NumCom & \# Companies Registered & + & $\begin{array}{c}\text { Higher number of companies } \rightarrow \text { More space used for business } \rightarrow \text { Higher } \\
\text { demand for land } \rightarrow \text { Higher land prices }\end{array}$ \\
\hline NumGuests & $\begin{array}{l}\text { \# Guests in General } \\
\text { Hotel }\end{array}$ & + & $\begin{array}{l}\text { Number of guests is an indicator of more tourism coming in. } \\
\text { Higher number of guests } \rightarrow \text { Increased development of attractions, } \\
\text { and improvement of infrastructures } \rightarrow \text { Land prices increase }\end{array}$ \\
\hline Internet & Internet Penetration Rate & + & $\begin{array}{c}\text { Better internet access is an indicator of developmental improvement } \rightarrow \\
\text { Higher land prices }\end{array}$ \\
\hline FTZ & $\begin{array}{l}\text { Existence of Free Trade } \\
\text { Zone }\end{array}$ & + & $\begin{array}{c}\text { Attracts more business activities } \rightarrow \text { Higher demand } \rightarrow \text { Land prices } \\
\text { increase }\end{array}$ \\
\hline AirDist & Distance to Airport & + & $\begin{array}{l}\text { Further from airports } \rightarrow \text { Less noise pollution and less transportation } \\
\text { competition } \rightarrow \text { More attractive to buyers } \rightarrow \text { Higher land prices }\end{array}$ \\
\hline
\end{tabular}

The descriptive statistics are given in Table 3 below. 
Table 3. Descriptive statistics of data set before and after the introduction of HSR.

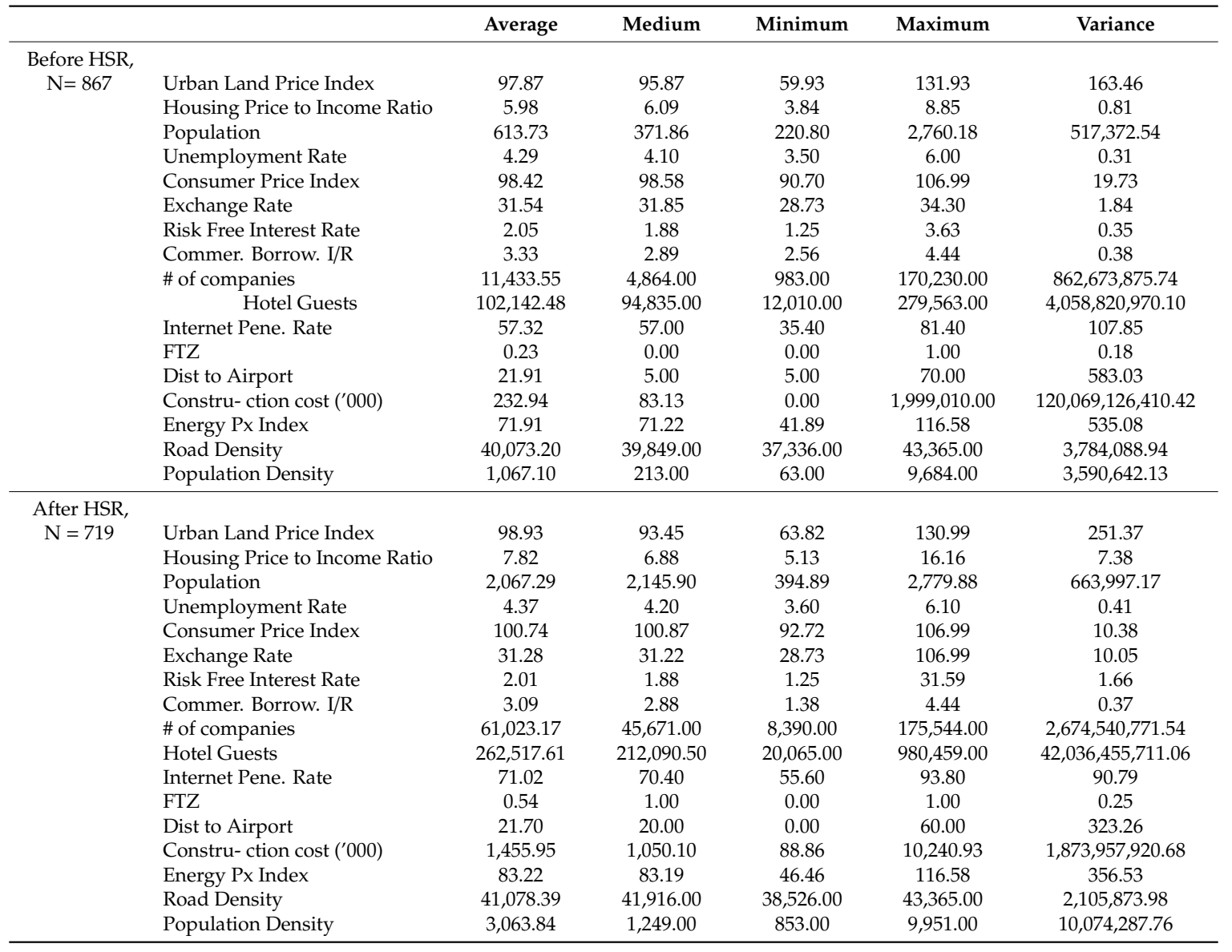

\subsection{Determining Factors Affecting Land Prices}

Monthly data were collected from the CEIC Database [48] for six cities with HSR stations (i.e., Taipei, Kaohsiung, Taichung, Tainan, Hsinchu, and Taoyuan) and five cities without HSR stations (i.e., Keelung, Hualien, Yilan, Taitung, and Nantou) across a period of twelve years that spanned between 2005 and 2016. This time period captured the data prior to the implementation of HSR in 2005 until 2016 inclusive. For data that were only provided in quarterly averages, the values were duplicated for each month in the quarter.

The base model is a full multivariate linear regression on all the data collected as shown the Equation (1).

$$
\begin{aligned}
U L P I_{1} & =\beta_{0}+\beta_{1}(\text { HSR })+\beta_{2}(H \$ I)+\beta_{3}(\text { GenPop })+\beta_{4}(\text { UnEmp })+\beta_{5}(\text { CPI })+\beta_{6}(\text { Fprex }) \\
+ & \beta_{7}(\text { IRrf })+\beta_{8}(5 \text { BankIR })+\beta_{9}(\text { NumCom })+\beta_{10}(\text { NumGuests })+\beta_{11}(\text { Internet }) \\
& +\beta_{12}(\text { FTZ })+\beta_{13}(\text { AirDist })+\beta_{14}(C C)+\beta_{15}(\text { Energy })+\beta_{16}(\text { RoadDen })+\varepsilon
\end{aligned}
$$

The regression model was estimated using ordinary least squares (OLS). The model fit reported a high $R^{2}$ value of $85 \%$, meaning that the explanatory variables provided a high explanatory power of land prices. However, the model in (1) suggests that "HSR" and "risk-free interest rates" variables were insignificant at a 99\% confidence level with $p$-values greater than 0.01 (Figure 5). 


\begin{tabular}{|c|c|c|c|c|c|}
\hline & Coefficients & Standard Error & tStat & $P$-value & VIF \\
\hline Intercept & -72.99 & 10.07 & -7.25 & 0.00 & 0.00 \\
\hline High Speed Rail Station & 0.45 & 0.50 & 0.89 & 0.37 & 3.26 \\
\hline Housing Price to Income Ratio & 0.76 & 0.16 & 4.81 & 0.00 & 5.96 \\
\hline General Population & 0.00 & 0.00 & -7.22 & 0.00 & 5.89 \\
\hline Unemployment Rate & -7.69 & 0.40 & -19.09 & 0.00 & 2.99 \\
\hline Consumer Price Index & 1.53 & 0.11 & 14.31 & 0.00 & 10.07 \\
\hline Exchange Rate & 1.34 & 0.19 & 7.02 & 0.00 & 3.75 \\
\hline Risk Free Interest Rate & 0.84 & 0.90 & 0.94 & 0.35 & 16.43 \\
\hline Commercial Borrowing I/R & -4.84 & 1.03 & -4.72 & 0.00 & 21.41 \\
\hline \#Companies Registered & 0.00 & 0.00 & -21.13 & 0.00 & 7.70 \\
\hline \# Guests in General Hotel & 0.00 & 0.00 & 23.21 & 0.00 & 5.43 \\
\hline Internet Penetration & -0.08 & 0.03 & -2.23 & 0.03 & 7.52 \\
\hline Free Trade Zone & 3.50 & 0.45 & 7.75 & 0.00 & 2.48 \\
\hline Distance to Airport & 0.04 & 0.01 & 6.11 & 0.00 & 1.89 \\
\hline Construction Cost & 0.00 & 0.00 & 6.70 & 0.00 & 1.81 \\
\hline Energy Price Index & -0.15 & 0.02 & -9.07 & 0.00 & 6.80 \\
\hline Road Density & 0.00 & 0.00 & 2.74 & 0.01 & 14.55 \\
\hline \multicolumn{2}{|c|}{ Regression Statistics } & & & & \\
\hline Multiple R & 0.92 & & & & \\
\hline R Square & 0.85 & & & & \\
\hline Adjusted R Square & 0.85 & & & & \\
\hline Standard Error & 5.51 & & & & \\
\hline Observations & 1581 & & & & \\
\hline
\end{tabular}

Figure 5. Regression analysis outcome for the base model (1).

In the regression model represented with Equation (1), ten explanatory variables had a variance inflation factor (VIF) greater than five, indicating multi-collinearity. The estimated correlation matrix (Figure 6) shows the interdependency of each pair of explanatory variables. To eliminate multi-collinearity, the pairs of variables which showed high correlation $(>0.7)$ were identified, and variables with the highest VIFs were first eliminated. In this step, five variables that were removed were housing-price-to-income ratio $(H \$ I)$, commercial borrowing interest rate (5BankIR), number of companies registered (NumCom), energy price index (Energy), and road density (RoadDen). As the underlying effects of these variables were captured in other variables, their removals do not compromise the model's explanatory power. Eliminating these variables also complies with the principle of model parsimony (Since most existing literature would concur that a dense road network facilitates a fast commute from one location to another and increases the accessibility in a city, a high density road network should, in principle, increases land prices. However, the road network density was found to have dropped out of the set of significant predictors for land prices. This can be explained by the strong link between the advancement of a city's economic and infrastructure developments and the road network. For the same reason, the "number of companies" was not within the set of significant predictors for land prices. While the increase in the number of companies will bid up land prices, its effect would have been captured by the presence of the free trade zone (FTZ), low interest rates, and favorable exchange regimes that attract foreign direct investment and promote the establishment of companies in the city. As "energy prices" are part of the overall "construction cost", the former is also excluded to prevent multi-collinearity).

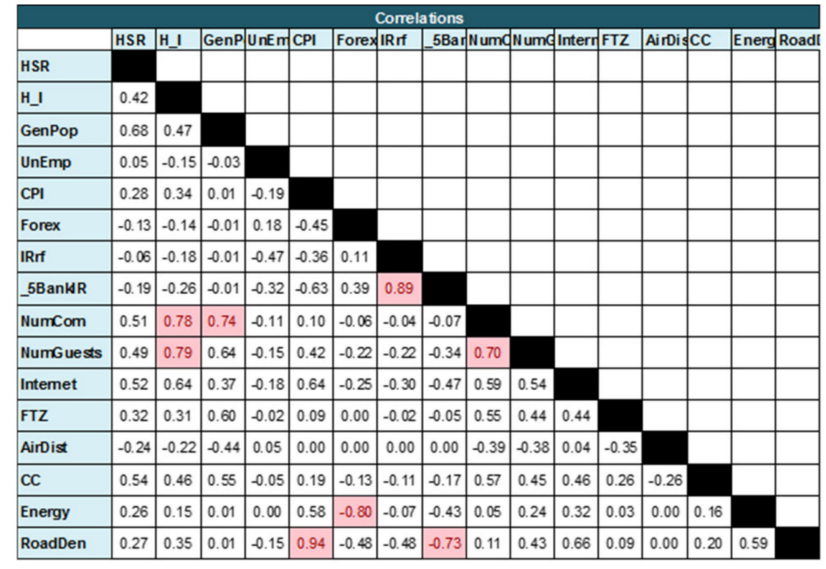

Figure 6. Correlation matrix of the base model (1). 
A reduced multivariate linear regression model constructed based on the eleven remaining explanatory variables is as follows:

$$
\begin{gathered}
\text { ULPI }_{2}=\beta_{0}+\beta_{1}(\text { HSR })+\beta_{3}(\text { GenPop })+\beta_{4}(\text { UnEmp })+\beta_{5}(\text { CPI })+\beta_{6}(\text { Frrex })+\beta_{7}(\text { IRrf }) \\
+\beta_{10}(\text { NumGuests })+\beta_{11}(\text { Internet })+\beta_{12}(\text { FTZ })+\beta_{13}(\text { AirDist })+\beta_{14}(C C)+\varepsilon
\end{gathered}
$$

In the model represented by Equation (2), all the explanatory variables including HSR and risk-free interest rate were significant with $p$-values less than 0.01 . The VIF were all below five (Figure 7). Errors followed a normal distribution as displayed in the histogram and normal probability plot (Appendix A). The $R^{2}$ value dropped slightly to $78 \%$ which is unsurprising, since the five variables

\begin{tabular}{|c|c|c|c|c|c|}
\hline & Coefficients & Standard Error & tStat & P-value & VIF \\
\hline Intercept & -126.26 & 9.24 & -13.67 & 0.00 & 0.00 \\
\hline High Speed Rail Station & 3.67 & 0.57 & 6.45 & 0.00 & 2.99 \\
\hline General Population & -0.01 & 0.00 & -16.05 & 0.00 & 4.49 \\
\hline Unemployment Rate & -10.85 & 0.39 & -27.68 & 0.00 & 2.66 \\
\hline Consumer Price Index & 2.27 & 0.07 & 33.55 & 0.00 & 3.71 \\
\hline Exchange Rate & 2.69 & 0.13 & 20.10 & 0.00 & 3.72 \\
\hline Risk Free Interest Rate & -6.76 & 0.38 & -17.59 & 0.00 & 2.71 \\
\hline \# Guests in General Hotel & $3.60 \mathrm{E}-05$ & 0.00 & 22.55 & 0.00 & 2.64 \\
\hline Internet Penetration & -0.48 & 0.03 & -16.06 & 0.00 & 4.09 \\
\hline Free Trade Zone & 4.49 & 0.51 & 8.74 & 0.00 & 2.27 \\
\hline Distance to Airport & 0.10 & 0.01 & 12.38 & 0.00 & 1.65 \\
\hline Construction Cost & 4.97E- 07 & 0.00 & 2.56 & 0.01 & 1.78 \\
\hline \multicolumn{2}{|c|}{ Regression Statistics } & & & & \\
\hline Multiple R & 0.89 & & & & \\
\hline R Square & 0.78 & & & & \\
\hline Adjusted R Square & 0.78 & & & & \\
\hline Standard Error & 6.56 & & & & \\
\hline Observations & 1581 & & & & \\
\hline
\end{tabular}
that were removed could have caused the $R^{2}$ value to decrease mathematically [49].

Figure 7. Regression analysis outcome for the reduced multivariate regression model (2).

Equation (2) shows that the establishment of a free trade zone (FTZ), the presence of a high-speed rail (HSR) station, consumer price index $(C P I)$, and exchange rate are positively related to land prices in Taiwan. Comparatively, the magnitude of the construction cost, size of the tourism industry, and the distant airport marginally increase land prices. The free-trade zone (FTZ) and stronger exchange rate contribute to the economic growth by increasing the earnings from trade. The presence of HSR station improves the attractiveness of an area via better accessibility that boosts the demand and pushes up the land prices of an area. Meanwhile, higher CPI reflects higher inflation rates which will be factored into the market property prices. The same applies to construction cost where higher construction cost translates into higher property prices. Although the presence of an airport boosts intercity and regional/ global connectivity, land prices are found to increase with distance away from an airport. Common with intuition, unemployment and interest rates (IRrf) exhibit negative correlations with land price, as higher rates lead to lower housing affordability.

More interestingly, the degree of internet penetration and size of the general population are found to exhibit negative relationships with land prices. The negative association with "internet penetration" can be explained in two ways. First, "internet penetration" supports ecommerce that alleviates the need of physical space for retail and office. Second, the vast availability of information found on the Internet might make it easier for people to recognize the market rates of land prices, hence increasing competition in the market and driving down the ULPI. This is especially true in the case of a larger population, where there will be more houses on the market. If the market behaves as a monopolistic competition, price competition of similar types of property will cause property prices to fall. Also, when a high-speed rail station is present in a densely populated city, it helps to bring the population away to other neighboring areas. This helps to decrease the demand pressure and reduce the prices for housing. 


\subsection{The Contribution of HSR to Land Prices}

The regression results above show that the HSR, as a representative variable for accessibility, displays a positive relationship on the land price, given presence of other contributable variables relating to economics, infrastructural and social factors. There is reason to believe that the impact of HSR on land prices may vary when underlying conditions governing these controlling factors change. In this sub-section, a principal component analysis (PCA) is carried out to observe associations among the variables used in Equation (2).

Table 4 shows the loadings of the variables on the principal components in three-, four-, and five-dimensional spaces. When observing the three-dimensional principal components model outcome, it was found that HSR is associated with GenPop, NumGuests, FTZ, AirDist, and CC in the first component. The size of general population and the number of guests provide justifications for the setting up an HSR station in a city. A longer distance away from the airport also means the HSR is necessary to provide connectivity between the city and the rest of the country, especially in support of the required transportation for functioning of the free trade zone. The connection between the Taoyuan HSR station to Taoyuan International Airport is a representative example. There is also a negative relationship between the size of the general population and the distance to an airport, simply because residents are less willing to stay nearby to airports (as hypothesized in the casual loop diagram in Section 3) and an airport needs a large space to operate. The positive correlation with the construction cost is likely to reflect the constrained supply of housing when constructions cost and demands for housing in a densely populated city are concurrently higher. The second component saw a positive association between CPI and internet and a negative correlation with Forex. The degree of internet penetration is generally associated with the level of urbanization of a city which, in turn, correlates with higher prices. On the other hand, a weak exchange rate regime dampens demands and lower prices. The third component comprises the UnEmp and IRrf, where the two variables relate negatively to each other.

Table 4. Variable loadings for 3, 4, and 5 principal component (PC) models.

\begin{tabular}{cccccccccccccc}
\hline & \multicolumn{3}{c}{ 3-PC Model } & \multicolumn{3}{c}{ 4-PC Model } & \multicolumn{4}{c}{ 5-PC Model } \\
\hline & PC1 & PC2 & PC3 & PC1 & PC2 & PC3 & PC4 & PC1 & PC2 & PC3 & PC4 & PC5 \\
\hline HSR & 0.722 & 0.256 & 0.101 & 0.830 & 0.081 & 0.051 & -0.033 & 0.849 & 0.115 & 0.192 & 0.052 & -0.019 \\
GenPop & 0.918 & -0.021 & -0.020 & 0.816 & -0.110 & -0.040 & -0.413 & 0.722 & -0.101 & 0.448 & -0.040 & -0.343 \\
NumGuests & 0.708 & 0.421 & 0.027 & 0.618 & 0.407 & 0.036 & -0.408 & 0.463 & 0.399 & 0.494 & 0.031 & -0.318 \\
FTZ & 0.703 & 0.022 & -0.017 & 0.568 & -0.002 & -0.015 & -0.424 & 0.208 & -0.060 & 0.834 & -0.023 & -0.242 \\
AirDist & -0.604 & 0.199 & 0.084 & -0.165 & 0.009 & 0.009 & 0.909 & -0.170 & -0.002 & -0.194 & 0.007 & 0.895 \\
CC & 0.653 & 0.239 & 0.047 & 0.735 & 0.091 & 0.005 & -0.057 & 0.835 & 0.140 & 0.034 & 0.008 & -0.082 \\
CPI & 0.076 & 0.883 & 0.106 & 0.221 & 0.861 & 0.106 & 0.099 & 0.092 & 0.846 & 0.253 & 0.097 & 0.158 \\
Forex & 0.042 & -0.673 & 0.124 & 0.047 & -0.753 & 0.091 & 0.102 & -0.096 & -0.788 & 0.244 & 0.092 & 0.170 \\
Internet & 0.454 & 0.725 & 0.100 & 0.659 & 0.549 & 0.050 & 0.200 & 0.443 & 0.521 & 0.569 & 0.040 & 0.326 \\
UnEmp & -0.022 & -0.322 & 0.861 & -0.029 & -0.329 & 0.858 & 0.020 & 0.050 & -0.308 & -0.138 & 0.862 & -0.013 \\
IRrf & -0.021 & -0.341 & -0.837 & -0.064 & -0.360 & -0.850 & 0.005 & 0.007 & -0.355 & -0.138 & -0.846 & -0.028 \\
\hline
\end{tabular}

When the PCA reduces the dataset into 5 components, HSR, GenPop, and CC are positively correlated with one another in component 1, while NumGuests, FTZ, and internet also positively correlated with one another in component 3 . As before, CPI negatively correlated with Forex in component 2 and UnEmp and IRrf continue to relate negatively to each other in the component 4 . AirDist becomes a standalone exogenous factor. Approximately $65 \%$ and $80 \%$ of the variance are explained using 3 and 5 principal components, respectively (Figure 8). 


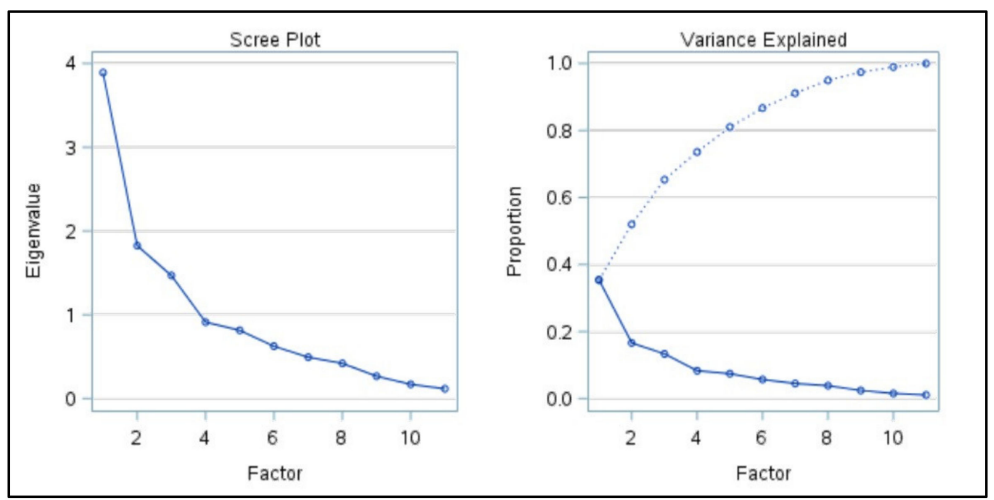

Figure 8. Eigenvalues and proportion from the PCA results.

It is noted that amidst the strong correlations among variables within a component, the components or dimensions are independent of one another. The variable loadings on the components reveal that HSR stations, the size of population, and construction cost are correlated positively and closely. A two-way relationship could be inferred such that the existence of HSR stations makes it attractive for people to settle in the city and the bigger population also contributes to the utilization of HSR. The latter justifies the high construction cost. These factors reinforce one another and together they increase land prices.

\section{Conclusions}

This study examines the determinants of house price fundamentals across 11 cities in Taiwan and discusses the effect of the high-speed rail on real estate prices taking into consideration the unequal economic, societal, and infrastructure developments among the cities. As an alternative to the hedonic pricing model, this study used an integrated methodology composed of system dynamics, multivariate regression, and principal component analysis. The empirical analysis will cover a 12 year period between 2005 and 2016 inclusive. Through system dynamics, a casual loop diagram was drawn to hypothesize the possible system behavior of interacting variables in determining the land prices. The parameters estimated in a multivariable regression model were used to identify the directions and strength of relationships between these variables, representing stages of economic, societal and infrastructural development, and land prices. Finally, the interaction effect of HSR and the exogenous environment was investigated via principal component analysis.

Despite the use of a different methodology, the results obtained were relatively consistent with those in the existing literature. The existence of HSR was found to increase land prices most significantly when economic conditions were promising, consumer prices were high, and unemployment rates were low. Favorable exchange rates and low lending rates coupled with the presence of a free trade zone that encouraged foreign investment and stimulated commercial activities exerted positive effects on housing prices. To a lesser extent, construction costs and a more distant airport also increased real estate prices. These results are similar to Ma et al. [50] who had shown that strong local economic development created additional employment and increased immigration in most Australian capital cities, especially Sydney and Brisbane, and pushed up property prices. In another study, Savva [51] found that population, economic growth, stock returns, and inflation were key factors for the increase in house prices indexes in 24 European cities. Construction cost is associated with housing prices, while interest and unemployment rates adversely affect housing prices.

More notably, findings from this study indicated negative relationships between the degree of internet penetration and population size and property prices in the presence of the HSR. The findings can be interpreted as such: A high degree of internet penetration supports ecommerce which alleviates the need of physical space for retail and office and aids in the dissemination of information on real estate availability. For cities with larger populations, the supply of houses on the market will also be larger. 
An efficient information flow drives the market to behave in a monopolistic competitive manner and price competition among similar types of property will cause property prices to fall. Also, when a high-speed rail station is present in a densely populated city, it helps to bring the population away to other neighboring areas. This helps to decrease the demand pressure and reduce the prices for housing. Meanwhile, a large population contributes to the HSR ridership and justifies the economic cost of constructing and running the HSR. Overall, the study suggests that HSR should be introduced in cities where the population density and internet penetration are high and the airport is far away. In doing so, the city can enjoy the enhanced accessibility while mitigating the increase in land prices brought about by the HSR.

Taking a step further, the adoption rate of the HSR can be included for a more accurate quantification of the impact of HSR on accessibility and land prices. Chou et al. [52] termed HSR accessibility service to be one that considers qualities such as punctuality and departure schedules, service quality, passenger satisfaction, passenger loyalty, corporate image, and operations performance. Another avenue for research is to conduct cross-country comparisons which allow for controlling factors useful in ascertaining the causation effect between HSR and land prices.

Author Contributions: Conceptualization, J.M.W.L.; methodology, J.M.W.L. and B.K.L.; software, J.M.W.L.; validation, J.M.W.L. and B.K.L.; formal analysis, B.K.L.; investigation, B.K.L.; writing-original draft preparation, B.K.L.; writing-review and editing, J.M.W.L. All authors have read and agreed to the published version of the manuscript.

Funding: This research received no external funding.

Conflicts of Interest: The authors declare no conflict of interest.

\section{Appendix A}

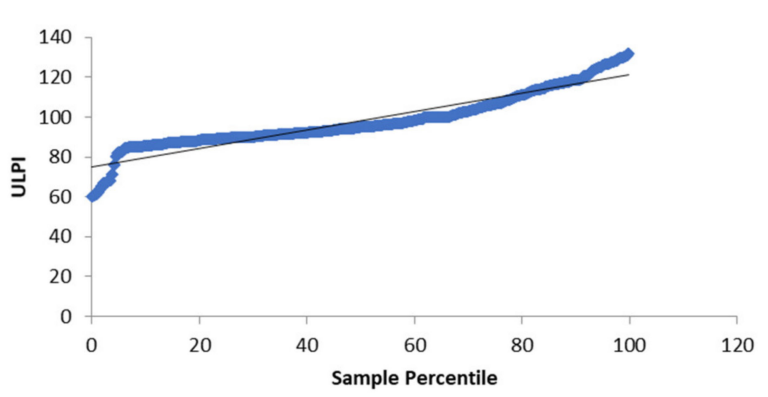

Figure A1. Normality probability plot for regression model (2).

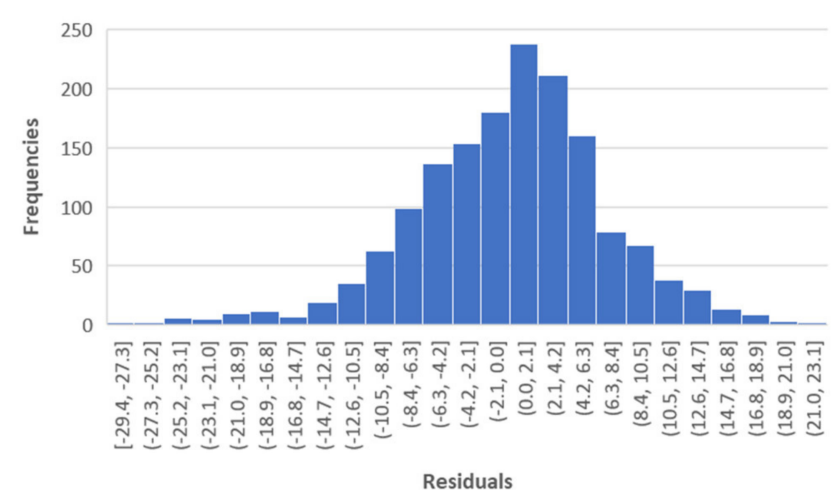

Figure A2. Normality probability histogram for regression model (2).

\section{References}

1. Li, Y.-T.; Schmöcker, J.-D. Adaptation patterns to high speed rail usage in Taiwan and China. Transportation 2016, 44, 807-830. [CrossRef]

2. Taiwan high-speed rail project. Available online: https:/www.daiho.co.jp/english/fpd/taiwan/taiwan.html (accessed on 12 May 2020). 
3. Kanasugi, H.; Ushijima, K. The impact of a high-speed railway on residential land prices. Pap. Reg. Sci. 2017, 97, 1305-1335. [CrossRef]

4. Andersson, D.E.; Shyr, O.F.; Fu, J. Does high-speed rail accessibility influence residential property prices? Hedonic estimates from southern Taiwan. J. Transp. Geogr. 2010, 18, 166-174. [CrossRef]

5. House prices in Taiwan. Available online: https://www.globalpropertyguide.com/Asia/Taiwan/Home-PriceTrends (accessed on 12 May 2020).

6. Andersson, D.E.; Shyr, O.F.; Lee, A. The successes and failures of a key transportation link: accessibility effects of Taiwan's high-speed rail. Ann. Reg. Sci. 2010, 48, 203-223. [CrossRef]

7. Matthews, C.; The 10 Hottest Real Estate Markets around the World. TIME. 2013. Available online: http://business.time.com/2013/12/16/the-10-hottest-real-estate-markets-around-the-world/ (accessed on 14 April 2020).

8. Rosen, S. Hedonic Prices and Implicit Markets: Product Differentiation in Pure Competition. J. Political Econ. 1974, 82, 34-55. [CrossRef]

9. Chen, Z.; Haynes, K.E. Impact of high speed rail on housing values: an observation from the Beijing-Shanghai line. J. Transp. Geogr. 2015, 43, 91-100. [CrossRef]

10. Geng, B.; Bao, H.; Liang, Y. A study of the effect of a high-speed rail station on spatial variations in housing price based on the hedonic model. Habitat Int. 2015, 49, 333-339. [CrossRef]

11. Brandt, S.; Maennig, W. The impact of rail access on condominium prices in Hamburg. Transportation 2011, 39, 997-1017. [CrossRef]

12. Szczepańska, A.; Senetra, A.; Wasilewicz-Pszczółkowska, M. The effect of road traffic noise on the prices of residential property-A case study of the polish city of Olsztyn. Transp. Res. Part D Transp. Environ. 2015, 36, 167-177. [CrossRef]

13. Szczepańska, A.; Senetra, A.; Wasilewicz-Pszczółkowska, M. The Influence of Traffic Noise on Apartment Prices on the Example of a European Urban Agglomeration. Sustainability 2020, 12, 801. [CrossRef]

14. Ozdenerol, E.; Huang, Y.; Javadnejad, F.; Antipova, A. The impact of traffic noise on housing values. J. Real Estate Pract. Educ. 2015, 18, 35-53. [CrossRef]

15. Kuehnel, N.; Moeckel, R. Impact of simulation-based traffic noise on rent prices. Transp. Res. Part D Transp. Environ. 2020, 78, 102191. [CrossRef]

16. Hall, F.L.; Breston, B.E.; Taylor, S.M. Effects of highway noise on residential property values. Transp. Res. 1978, 686, 38-43.

17. Taylor, S.; Breston, B.; Hall, F. The effect of road traffic noise on house prices. J. Sound Vib. 1982, 80, 523-541. [CrossRef]

18. Karanikolas, N.; Vagiona, D.; Xifilidou, A. Real estate values and the environment: A case study on the effect of the environment on residential real estate values. Int. J. Acad. Res. 2011, 3, 861-868.

19. Getzner, M.; Färber, B.; Yamu, C. 2D Versus 3D: The Relevance of the Mode of Presentation for the Economic Valuation of an Alpine Landscape. Sustainability 2016, 8, 591. [CrossRef]

20. Ersöz, F.; Ersoz, T.; Soydan, M. Research on Factors Affecting Real Estate Values by Data Mining. Balt. J. Real Estate Econ. Constr. Manag. 2018, 6, 220-239. [CrossRef]

21. Haynes, K.E. Labor markets and regional transportation improvements: the case of high-speed trains. Ann. Reg. Sci. 1997, 31, 57-76. [CrossRef]

22. Sasaki, K.; Ohashi, T.; Ando, A. High-speed rail transit impact on regional systems: does the Shinkansen contribute to dispersion? Ann. Reg. Sci. 1997, 31, 77-98. [CrossRef]

23. Kim, H.-W.; Lee, D.-H.; Park, H.-S. The impact of Gyeongbu High Speed Rail construction on regional economic growth. KSCE J. Civ. Eng. 2013, 17, 1206-1212. [CrossRef]

24. Jia, S.; Zhou, C.; Qin, C. No difference in effect of high-speed rail on regional economic growth based on match effect perspective? Transp. Res. Part A Policy Pr. 2017, 106, 144-157. [CrossRef]

25. Vickerman, R. Can high-speed rail have a transformative effect on the economy? Transp. Policy 2018, 62, 31-37. [CrossRef]

26. Hiramatsu, T. Unequal regional impacts of high speed rail on the tourism industry: a simulation analysis of the effects of Kyushu Shinkansen. Transportation 2016, 45, 677-701. [CrossRef]

27. Morris, J.; Dumble, P.; Wigan, M. Accessibility indicators for transport planning. Transp. Res. Part A Gen. 1979, 13, 91-109. [CrossRef]

28. Alonso, W. Location and Land Use; Harvard University Press: Cambridge, MA, USA, 1964. 
29. Muth, R.F. Cities and Housing: The Spatial Pattern of Urban Residential Land Use; University of Chicago Press: Chicago, IL, USA, 1969.

30. Drachal, K.; Krzysztof, D. Property prices and regional labor markets in Poland. Singidunum J. Appl. Sci. 2014, 11, 5-15. [CrossRef]

31. Gan, L.; Wang, P.; Zhang, Q. Market thickness and the impact of unemployment on housing market outcomes. J. Monetary Econ. 2018, 98, 27-49. [CrossRef]

32. Drachal, K. House prices and unemployment: A recent evidence from Poland. Urban 2016, 7, 43-56.

33. Branch, W.A.; Petrosky-Nadeau, N.; Rocheteau, G. Financial frictions, the housing market, and unemployment. J. Econ. Theory 2016, 164, 101-135. [CrossRef]

34. Lee, S.S. Economic Growth Key to Singapore's Property Fortunes The Straits Times. 2015. Available online: http://www.straitstimes.com/opinion/economic-growth-key-to-singapores-property-fortunes (accessed on 14 April 2020).

35. Florida, R.; Internet Connectivity and Economic Development. The Atlantic Daily. 2010. Available online: https://www.theatlantic.com/technology/archive/2010/07/internet-connectivity-andeconomic-development/60639/ (accessed on 12 May 2020).

36. Hensher, D.; Li, Z.; Mulley, C. The impact of high speed rail on land and property values: A review of market monitoring evidence from eight countries. Road Transp. Res. 2012, 21, 3-14.

37. Nasereddin, H.H.O. Internet penetration and the constraints on the Use of E-commerce. J. Inform. Tech. Rev. 2011, 2, 66-72.

38. James, M. The SAGE handbook of tourism studies. J. Sustain. Tour. 2013, 21, 1245-1247. [CrossRef]

39. Tsai, H.; Huang, W.-J.; Li, Y. The Impact of Tourism Resources on Tourism Real Estate Value. Asia Pac. J. Tour. Res. 2015, 21, 1114-1125. [CrossRef]

40. Chen, N.-K. Bank net worth, asset prices and economic activity. J. Monetary Econ. 2001, 48, 415-436. [CrossRef]

41. Gerlach, S.; Peng, W. Bank lending and property prices in Hong Kong. J. Bank. Finance 2005, $29,461-481$. [CrossRef]

42. Tsatsaronis, K.; Zhu, H. What drives housing price dynamics: Cross-country evidence. BIS Q. Rev. 2004, 65-78. Available online: https://ssrn.com/abstract=1968425 (accessed on 14 April 2020).

43. Somerville, C.T. Residential Construction Costs and the Supply of New Housing: Endogeneity and Bias in Construction Cost Indexes. J. Real Estate Finance Econ. 1999, 18, 43-62. [CrossRef]

44. Rao, C.; Ge, Y. Analysis of Main Influence Factors for Housing Prices. In Proceedings of the 2015 International Conference on Engineering Management, Engineering Education and Information Technology, Guangzhou, China, 24-25 October 2015; Atlantis Press: Paris, France, 2015.

45. Feng, C.M. Lesson learnt from Taiwan high speed rail. In Proceedings of the 9th International Conference of Eastern Asia Society for Transportation Studies, Jeju, South Korea, 30 September 2011; pp. 1-13. [CrossRef]

46. Zheng, S.; Kahn, M.E. Land and residential property markets in a booming economy: New evidence from Beijing. J. Urban Econ. 2008, 63, 743-757. [CrossRef]

47. Bureau of High Speed Rail. Available online: https://www.hsr.gov.tw (accessed on 14 April 2020).

48. CEIC Database. Available online: https://www.ceicdata.com (accessed on 12 May 2020).

49. Dalgaard, P. Introductory Statistics with R; Springer: New York, NY, USA, 2008.

50. Le Ma Deakin University Gheringhap Street Geelong Victoria Australia; Liu, C. The impacts of residential construction and property prices on residential construction outputs: an inter-market equilibrium approach. Int. J. Strat. Prop. Manag. 2017, 21, 296-306. [CrossRef]

51. Savva, C.S. Factors affecting housing prices: International evidence. Cyprus Econ. Policy Rev. 2018, 12, 87-96.

52. Chou, J.-S.; Kim, C.; Tsai, P.-Y.; Yeh, C.-P.; Son, H. Longitudinal assessment of high-speed rail service delivery, satisfaction and operations: A study of Taiwan and Korea systems. KSCE J. Civ. Eng. 2017, 21, 2413-2428. [CrossRef]

(C) 2020 by the authors. Licensee MDPI, Basel, Switzerland. This article is an open access article distributed under the terms and conditions of the Creative Commons Attribution (CC BY) license (http://creativecommons.org/licenses/by/4.0/). 